\title{
Assessing the role of canopy cover on the colonization of phytotelmata by aquatic invertebrates: an experiment with the tank-bromeliad Aechmea lingulata
}

\author{
Juliana V. RANGEL, ${ }^{1,2}$ Rosângela E.S. ARAÚJO, ${ }^{1,2}$ Cinthia G. CASOTTI, ${ }^{1,2}$ Larissa C. COSTA,,${ }^{1,2}$ Walace P. KIFFER Jr., ${ }^{1,2}$ \\ Marcelo S. MORETTI ${ }^{1,2^{*}}$ \\ ${ }^{1}$ Laboratory of Aquatic Insect Ecology, University of Vila Velha, Av. Comissário José Dantas de Melo 21, Vila Velha 29.102-920; \\ ${ }^{2}$ Graduate Program in Ecosystem Ecology, University of Vila Velha, Av. Comissário José Dantas de Melo 21, Vila Velha 29.102-920, Brazil \\ *Corresponding author: marcelo.moretti@uvv.br
}

\begin{abstract}
The presence of canopy cover may influence the amount of organic detritus and stored water in bromeliad tanks and, consequently, the colonization of these ecosystems by aquatic invertebrates. The aim of this study was to determine the effects of canopy cover on the colonization of the tank-bromeliad Aechmea lingulata in the restinga, an ecosystem composed of a variety of plant communities in the sandy coastal plains of Brazil. We hypothesized that the taxonomic composition of invertebrate communities would differ between bromeliads covered and not covered by a dense canopy (shaded and unshaded bromeliads). Prior to the beginning of the experiment, bromeliads of similar size were carefully washed to remove all organisms and organic detritus, and their tanks were filled with $1.0 \mathrm{~L}$ of spring water. On days $7,14,21,30,45,60$ and 90 , four bromeliad tanks of each shade treatment were sampled to determine invertebrate communities, stored water and organic detritus. Average daily values of water temperature and light intensity were higher in unshaded than in shaded bromeliads. The amount of fine particulate organic matter (FPOM) and stored water did not differ between treatments, but the amount of coarse particulate organic matter (CPOM) was higher in shaded bromeliads. Ostracoda, Hydracarina and Oligochaeta were the most abundant taxa in bromeliad tanks. Among insects, Culicidae, Chironomidae and Ceratopogonidae were the most representative. Invertebrate colonization occurred quickly and values of abundance were higher in unshaded bromeliads compared to shaded bromeliads. The values for biomass and richness did not differ between treatments or colonization times, and the taxonomic composition of invertebrate communities was similar throughout the experiment. Our results showed that canopy cover had a small influence on the colonization of tanks of $A$. lingulata in restinga, not corroborating the proposed hypothesis. These findings were likely due to the lack of variation in environmental conditions that are relevant to the colonization process, such as stored water and FPOM. However, because the amounts of CPOM were higher in shaded bromeliads, the taxonomic composition of invertebrate communities could have differed if typical shredders were present.
\end{abstract}

Key words: Bromeliaceae; habitat availability; organic detritus; invertebrate biomass; restinga ecosystem.

Received: June 2016. Accepted: November 2016.

\section{INTRODUCTION}

Phytotelmata, temporary water bodies held by terrestrial plants, are useful and valuable models for the study of ecological processes (Srivastava et al., 2004; Brendonck et al., 2010). These ecosystems are easy to handle due to the small size and well-defined physical limits (Kitching, 2000; Srivastava et al., 2004; Srivastava, 2006). Their efficiency was tested by different authors who concluded that natural microcosms are as versatile as artificial ones and, at the same time, exhibit the same biological complexity as other ecosystems (Blaustein and Schwartz, 2001; Srivastava et al., 2004; Jocque and Field, 2014). Several studies have used phytotelm ecosystems to assess insect-plant interactions, processes of colonization (Richardson and Hull, 2000), nutrient cycling (Kitching, 2001), community interactions such as predation (Hammill et al., 2015) and competition (Naeem, 1990b;
Barberis et al., 2013), and patterns of ecological succession (Murrell et al., 2014).

Phytotelm-based ecosystems are important landscape elements that provide habitat for aquatic organisms and contribute to the maintenance of local biodiversity (Naeem, 1990a; Kitching, 2000). Typically, organisms colonizing these ecosystems have a high degree of specificity and endemism (Little and Hebert, 1996; Vieira et al., 2008; Dunthorn et al., 2012) and are mainly represented by immature stages of insects and non-insect invertebrates that find optimal conditions for survival and breeding within phytotelmata (Frank, 1983). Phytotelmata are also important to terrestrial organisms that may use them as foraging sites (Maguire, 1971), refuge against predators (Domingos et al., 2015) and water sources (Frank and Lounibos, 2009). All these characteristics make such ecosystems attractive and suitable for the establishment of complex biological interactions (Richardson, 1999; Richardson and Hull, 2000). 
Compared to other aquatic ecosystems, the dynamics of biotic and abiotic factors in phytotelmata occur at short intervals, given that their permanence in the environment depends on the survival of host plants and rates of water collection and evaporation (Cogliatti-Carvalho et al., 2010; Dézerald et al., 2014). Therefore, small changes in the environmental conditions and characteristics of host plants may result in differences in the structure and composition of phytotelm communities (Ospina-Bautista et al., 2008; Dézerald et al., 2014; Cardoso et al., 2015). Armbruster et al. (2002) observed strong correlations among plant morphology and the volume of stored water with the abundance of organisms in bromeliad tanks. Moreover, the availability of nutrients (Richardson and Hull, 2000; Zytynska et al., 2012; Petermann et al., 2015) and solar radiation (Dézerald et al., 2014; Carrias et al., 2014) may change water chemical composition and, consequently, influence invertebrate colonization (Richardson, 1999; Gossner et al., 2016).

Most of the energy available to heterotrophic organisms in phytotelm ecosystems comes from organic detritus (Moore et al., 2004). Among these, leaf litter and fine particulate organic matter (FPOM) constitute the main food resources (Brouard et al., 2012). Abiotic (leaching) and biotic processes (microorganisms and invertebrate detritivores) (Graça, 2001) successively decompose this material. As in other aquatic ecosystems (Graça et al., 2015), the availability of organic detritus is a relevant factor to phytotelm communities (Walker et al., 1997; Brouard et al., 2012; Dézerald et al., 2013). Thus, both the quantity and quality of organic detritus can influence invertebrate abundance (Armbruster et al., 2002) and taxonomic richness (Kitching, 2000, 2001), as well as the biomass for functional feeding groups (Srivastava, 2006; Ptatscheck and Traunspurger, 2015).

Although organic detritus is considered an important energy source to phytotelm communities, the availability of light allows the establishment of primary producers (Marino et al., 2012; Leroy et al., 2013; Carrias et al., 2014). Furthermore, recent studies have found that food resources, i.e., algae and organic detritus, may vary in phytotelmata held by shaded and unshaded bromeliads (Yee and Willig, 2007; Brouard et al., 2012; Dézerald et al., 2014). According to Kaufman et al. (2006), in unshaded bromeliads, algae constitute a high energetic resource to consumers because they provide nutritionally important compounds such as sterols, fatty acids and organic carbon.

Restinga is the general name collectively given to a variety of plant communities found in the sandy coastal plains of Brazil (Scarano et al., 2002). In this ecosystem, tank-bromeliads occur at the border of clumps that have the central portion occupied by woody species (Scarano, 2002). In this study, we determined the effects of canopy cover on the colonization of tanks of Aechmea lingulata (L.) Baker (Bromeliaceae) by aquatic invertebrates. For this, we studied rosettes of $A$. lingulata in two areas of restinga where (i) the bromeliads were covered by a dense clump canopy (shaded bromeliads) and (ii) the bromeliads were not covered due the low height of woody species (unshaded bromeliads). Because differences in the amount of organic detritus and stored water were expected, we hypothesized that the taxonomic composition of invertebrate communities would differ between shaded and unshaded bromeliads.

\section{METHODS}

\section{Study area}

The colonization experiment was developed from June to September 2013 in two areas of restinga at the municipality of Guarapari (Espírito Santo State, SE Brazil). These areas were located at the Paulo César Vinha State Park (20³5'20' S - 40²5'02' W; shaded bromeliads) and the Environmental Protection Area of Setiba (20³4'55" S - 40²5'12" W; unshaded bromeliads). In both sites, the clonal tank-bromeliad A. lingulata is commonly found near woody species of the genus Clusia L. (Clusiaceae), forming clumps that are interspersed with sand ridges, in a physiognomy determined as non-flooded, open shrubby vegetation (Magnago, 2007). However, clumps in the environmental protection area have lower height and less dense canopies because this area was impacted by sand extraction activities during the 1980s and 1990s (IEMA, 2015).

The climate in the study area is classified as tropical wet and dry $(A w)$, with hot and rainy summers and dry winters. The average annual values of temperature and precipitation are $27.9^{\circ} \mathrm{C}$ and $1388 \mathrm{~mm}$, and the relative humidity is $80 \%$ (INMET, 2013). During the experiment, temperatures of stored water were higher in unshaded bromeliads $\left(23.9 \pm 0.6\right.$ to $\left.28.2 \pm 0.5^{\circ} \mathrm{C}\right)$, while levels of dissolved oxygen were higher in shaded bromeliads $(1.3 \pm 0.1$ to $\left.5.5 \pm 0.4 \mathrm{mg} \mathrm{L}^{-1}\right)$. Electrical conductivity measurements had a wide variation and were initially higher in shaded bromeliads $\left(30.8 \pm 16.8 \mu \mathrm{S} \mathrm{cm}^{-1}\right.$ at day 7$)$. However, after the first week of the experiment, higher conductivity values were observed in unshaded bromeliads. The physical and chemical properties of stored water in the tanks of studied bromeliads and values of accumulated rainfall during the experiment are presented in Tab. 1.

\section{Phytotelm characterization}

Prior to the beginning of the experiment, the average daily values of water temperature and light intensity and the percentage of canopy coverage were determined in 20 bromeliads (10 shaded and 10 unshaded). The values of 
water temperature and light intensity were measured for 10 days at regular intervals (every $15 \mathrm{~min}$ ) by data loggers (HOBO Pendant UA-002-64, Onset Computer Corporation, Bourne, Massachusetts, USA) submerged close to the water surface. The percentages of canopy coverage were determined by the analysis of photographs, taken with a digital camera (SONY Steady-Shot DSC-W610) positioned parallel to the ground and immediately above the tanks, using ImageJ Software (US National Institutes of Health, Bethesda, Maryland, USA).

\section{Experimental design}

In total, 72 rosettes of $A$. lingulata (36 shaded and 36 unshaded) were used in the experiment. In both study areas (625 $\mathrm{m}^{2}$ each), the bromeliads were distributed in 4-5 clumps, which were approximately $5 \mathrm{~m}$ distant from each other. These bromeliads were chosen because they presented similar values of external diameter (difference between means: $0.11 \mathrm{~cm}[95 \% \mathrm{CI}:-0.247,0.466])$ and maximum volume of water storage (difference between means: $0.05 \mathrm{~L}$ [95\% CI: $-0.003,0.100])$. At the beginning of the experiment, the bromeliads were carefully washed and rubbed to remove all organisms and organic detritus. After washing, the tank of each bromeliad was filled with $1.0 \mathrm{~L}$ of spring water for invertebrate colonization. Eight bromeliads of each shading treatment, which had not been washed, were used as controls to determine invertebrate communities, volumes of stored water and the amount of organic detritus in the tanks at the beginning and the end of the experiment (4 initial and 4 final controls per treatment).

On days 7, 14, 21, 30, 45, 60 and 90, four tanks of each treatment (one per clump) were sampled by turning the rosettes upside down, which is a non-destructive sampling method (Liria, 2007; Jabiol et al., 2009). The water trapped among leaves was removed with a pipette. The samples were individually placed in plastic containers and transported on the same day to the laboratory, where they were washed over a $250 \mu \mathrm{m}$ mesh. The material retained was preserved in $70 \%$ ethanol and posteriorly sorted under a stereomicroscope (Belphotonics STM-pro, Osasco, Brazil; 32x). Except for non-insect taxa, invertebrates found were identified to family level using specific identification keys (Merritt and Cummins, 1996; Costa et al., 2006; Mugnai et al., 2010; Triplehorn and Johnson, 2011). The presence of typical shredders of the tropical region, such as caddisflies of the genus Phylloicus Müller, 1880 and chironomids of the genera Stenochironomus Kieffer, 1919 and Chironomus Meigen, 1803 (Callisto et al., 2007), was evaluated in all samples. All individuals were then separated by taxon, counted, dried $\left(60^{\circ} \mathrm{C}, 72 \mathrm{~h}\right)$ and weighed by an analytical balance $( \pm 0.01 \mathrm{mg})$ for biomass determination. The initial (day 0 ) and final controls (day 90) of each treatment were sampled following the same procedures.

Leaf litter and small twigs found in the tanks were placed in plastic bags and posteriorly dried $\left(60^{\circ} \mathrm{C}, 72 \mathrm{~h}\right)$ and weighed $( \pm 0.01 \mathrm{~g})$ to determine the amount of coarse particulate organic matter $(\mathrm{CPOM}>1 \mathrm{~mm})$. After the removal of invertebrates and CPOM, the water of each sample was filtered over pre-weighed glass fiber GF/F filters (Sartorius Stedim Biotech) and the filters were dried $\left(60^{\circ} \mathrm{C}, 72 \mathrm{~h}\right)$ and calcined $\left(500^{\circ} \mathrm{C}, 4 \mathrm{~h}\right)$ for ash free dry mass (AFDM) determination of accumulated FPOM.

\section{Data analysis}

The values of water temperature, light intensity and percentage of canopy coverage of shaded and unshaded bromeliads were tested for normality and compared by $t$ tests. Because the total number of invertebrates found in bromeliads showed great variation (2 to 699 individuals), the rarefaction method was used to calculate the expected values of taxonomic richness in samples with standard-

Tab. 1. Abiotic water parameters in the phytotelmata of $A$. lingulata shaded and unshaded by the canopy cover during the colonization experiment. Rainfall accumulation during the study period is also shown.

\begin{tabular}{|c|c|c|c|c|c|c|c|}
\hline & \multicolumn{2}{|c|}{ Temperature $\left({ }^{\circ} \mathrm{C}\right)$} & \multicolumn{2}{|c|}{ Dissolved $\mathrm{O}_{2}\left(\mathrm{mg} \mathrm{L}^{-1}\right)$} & \multicolumn{2}{|c|}{ Conductivity $\left(\mu \mathrm{S} \mathrm{cm}^{-1}\right)$} & \multirow[t]{2}{*}{ Rainfall (mm) } \\
\hline & Shaded & Unshaded & Shaded & Unshaded & Shaded & Unshaded & \\
\hline Initial & $21.9 \pm 0.2$ & $25.3 \pm 0.5$ & $4.4 \pm 0.5$ & $4.5 \pm 0.3$ & $38.0 \pm 7.9$ & $25.8 \pm 10.9$ & - \\
\hline 7 & $22.1 \pm 0.6$ & $24.1 \pm 0.5$ & $5.5 \pm 0.4$ & $5.4 \pm 0.2$ & $30.8 \pm 16.8$ & $6.5 \pm 5.0$ & 5 \\
\hline 14 & $20.6 \pm 0.7$ & $23.9 \pm 0.6$ & $5.0 \pm 0.5$ & $2.1 \pm 0.5$ & $30.5 \pm 15.8$ & $42.6 \pm 16.8$ & 9 \\
\hline 21 & $26.0 \pm 0.5$ & $28.2 \pm 0.5$ & $3.5 \pm 0.5$ & $2.4 \pm 0.4$ & $16.5 \pm 5.4$ & $27.1 \pm 4.4$ & 25 \\
\hline 30 & $25.0 \pm 0.3$ & $25.8 \pm 0.1$ & $3.3 \pm 0.1$ & $3.6 \pm 0.1$ & $19.5 \pm 0.1$ & $21.0 \pm 0.1$ & 25 \\
\hline 45 & - & - & - & - & - & - & 25 \\
\hline 60 & $25.9 \pm 0.4$ & $27.3 \pm 0.5$ & $1.3 \pm 0.1$ & $1.3 \pm 0.1$ & $17.7 \pm 0.7$ & $23.9 \pm 4.9$ & 51 \\
\hline 90 & $22.0 \pm 0.2$ & $26.4 \pm 2.7$ & $5.2 \pm 0.2$ & $2.8 \pm 1.5$ & $10.6 \pm 0.1$ & $11.4 \pm 0.7$ & 73 \\
\hline Final & $23.8 \pm 1.6$ & $27.2 \pm 2.1$ & $4.6 \pm 0.3$ & $2.2 \pm 1.3$ & $47.0 \pm 0.1$ & $8.1 \pm 2.3$ & - \\
\hline
\end{tabular}

- , not measured because of the low volume of water. 
ized sizes $E\left(S_{n}\right)$ (Gotelli and Colwell, 2011). Analyses of Variance (ANOVA) were used to compare the values of abundance, rarefied richness and biomass of invertebrate communities across shade treatments and colonization times (factors). The volumes of stored water and the amount of CPOM and FPOM were also compared by ANOVA. The normality and homogeneity of variance were tested for all data. Additionally, we tested normality on the residuals from the ANOVAs for each response variable. When a model was significant, Tukey tests were used for post hoc comparisons (Zar, 2010). To evaluate the structure of invertebrate communities in shaded and unshaded bromeliads at different colonization times, a non-metric multidimensional scaling (NMDS) test was performed on the log-transformed abundance data followed by determining the Bray-Curtis distance (McCune and Grace, 2002). Analyses of similarities (ANOSIM, 999 permutations) were used to test for significant differences between the communities found in each shade treatment and colonization times (Clarke and Green, 1988). All statistical analyzes were performed using SPSS (version 23.0 for Macintosh, SPSS, Chicago, Illinois, USA) and Primer (version 6, Primer-E Ltd., Lutton, United Kingdom).

\section{RESULTS}

Shaded bromeliads showed higher percentages of canopy coverage than unshaded, by $66.5 \%$ on average (95\% CI: $59.284,73.611)$. Consequently, average daily values of water temperature and light intensity were higher in unshaded than shaded bromeliads (temperature: $1.5^{\circ} \mathrm{C}$ on average [ $95 \%$ CI: $\left.0.657,2.323\right]$; light intensity: 8943.8 Lux on average [95\% CI: 6315.2, 11572.1]).

During the experiment, the volume of stored water in bromeliads ranged from $18.7 \pm 10.9$ to $315.0 \pm 192.3 \mathrm{ml}$ (Fig. 1a). These values did not differ between treatments. However, values observed at day 21 were higher than those observed at days $30(202.50 \mathrm{ml}$ on average [95\% CI: $17.378,387.622]), 45(238.37 \mathrm{ml}$ on average [95\% CI: $53.253,423.497])$ and $90(236.50 \mathrm{ml}$ on average [95\% CI: $51.378,421.622]$ ) (treatment: $F_{1,56}=0.140, \mathrm{P}=0.711$; time: $F_{6,56}=4.335, \mathrm{P}=0.002$; interaction: $F_{6,56}=0.203$, $\left.\mathrm{P}=0.974 ; \mathrm{R}^{2}=0.395\right)$. Regarding the amount of organic detritus, the dry mass of CPOM and FPOM ranged from 0 to $3.22 \pm 1.62 \mathrm{~g}$ and $44.2 \pm 33.2$ to $463.5 \pm 141.7 \mathrm{mg}$, respectively (Fig. 1b,1c). The amount of CPOM was higher in the shaded bromeliads than in unshaded bromeliads, by $0.82 \mathrm{~g}$ on average $(95 \% \mathrm{CI}: 0.186,1.460)$ and did not differ among colonization times (treatment: $F_{1,56}=10.916$, $\mathrm{P}=0.002$; time: $F_{6,56}=1.514, \mathrm{P}=0.197$; interaction: $\left.F_{6,56}=1.396, \mathrm{P}=0.239 ; \mathrm{R}^{2}=0.403\right)$. The amount of FPOM did not differ between treatments or colonization times (treatment: $F_{1,56}=1.353, \mathrm{P}=0.251$; time: $F_{6,56}=0.954$, $\mathrm{P}=0.468$; interaction: $\left.F_{6,56}=0.973, \mathrm{P}=0.455 ; \mathrm{R}^{2}=0.235\right)$.
In total, 5206 (23 taxa) and 8714 (20 taxa) organisms were sampled in the shaded and unshaded bromeliads, respectively (Tab. 2). Ostracoda (Crustacea) was the most abundant taxon, accounting for approximately $46 \%$ of all sampled organisms. Hydracarina (Acari) and Oligochaeta (Annelida) were also abundant (16 and 15\%, respectively). Among insects, larvae of the dipteran families Culicidae (11\%), Chironomidae (6\%) and Ceratopogonidae $(3 \%)$ were the most representative.

The abundance of invertebrate communities ranged from $49.5 \pm 16.5$ to $269.0 \pm 81.3$ ind. (Fig. 2a). Invertebrate colonization occurred quickly in both shaded and unshaded bromeliads, and after day 14 , the values of abundance in experimental bromeliads were similar to those observed in the initial controls. However, the abundance
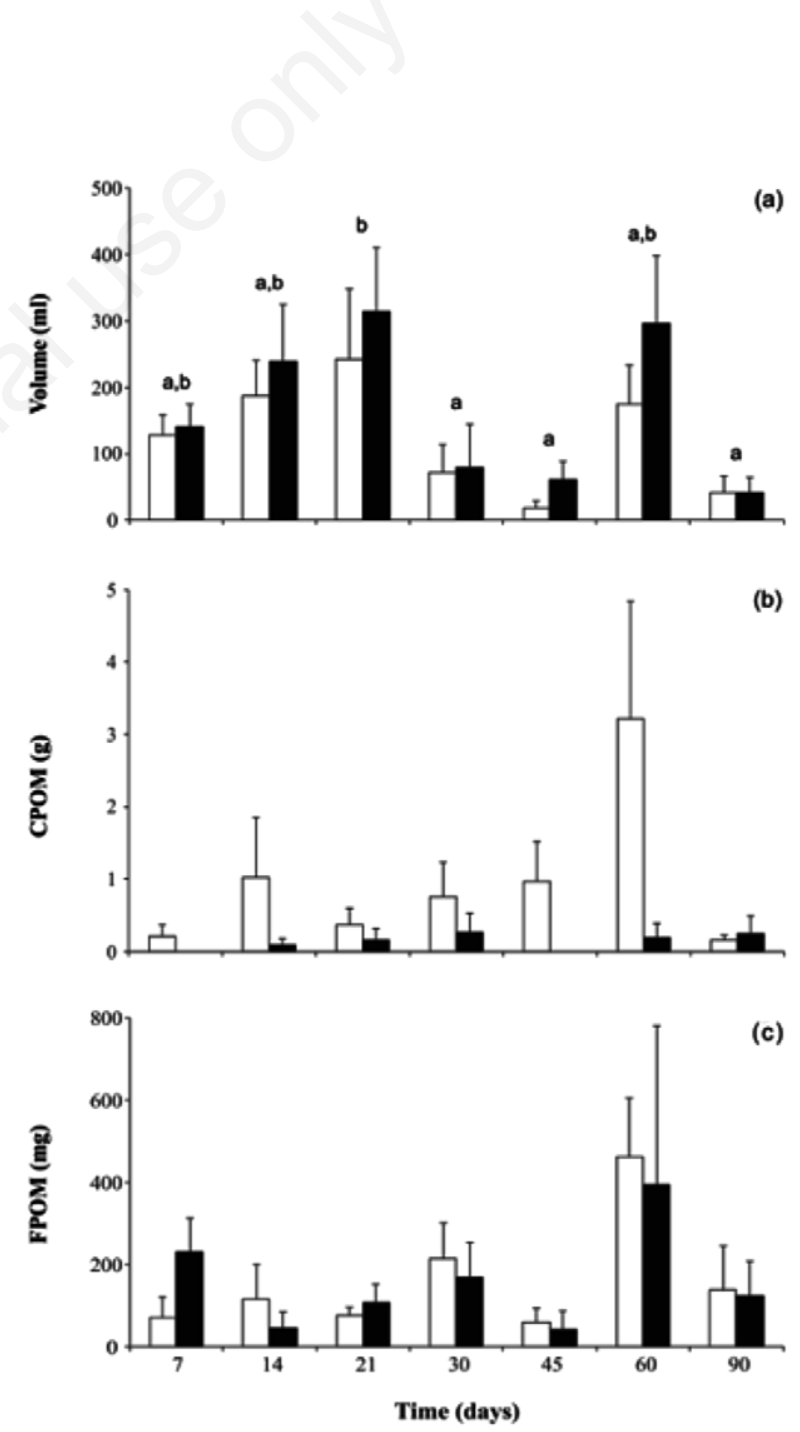

Fig. 1. Volume of stored water (a) and amount of CPOM (b) and FPOM (c, mean $\pm \mathrm{EP})$ observed in the phytotelmata of $A$. ling $u$ lata shaded (open bars) and unshaded (solid bars) by the canopy cover during the colonization experiment. Values with different superscript letters were significantly different. 
values for treatment bromeliads observed at the end of the experiment (day 90) were lower than those values observed in the final controls. During the experiment, values of abundance were higher in unshaded bromeliads, by 80.8 ind. on average (95\% CI: $5.177,156.484)$, and did not differ among colonization times (Tab. 3). Values of taxonomic richness ranged from $4.0 \pm 0.5$ to $6.0 \pm 0.4$ taxa (Fig. 2b). In both treatments, these values were higher in experimental bromeliads than in controls. Values of total invertebrate biomass showed high variation in unshaded bromeliads ( $3.8 \pm 1.0$ to $13.4 \pm 9.6 \mathrm{mg}$ ); these values were similar to controls in shaded bromeliads $(3.0 \pm 0.8$ to $8.4 \pm 3.5 \mathrm{mg}$, Fig. 2c). The richness and biomass of invertebrate communities did not differ between treatments or colonization times (Tab. 3).

Tab. 2. Relative abundance (\%) of the invertebrate taxa found in the phytotelmata of $A$. lingulata shaded and unshaded by the canopy cover during the colonization experiment.

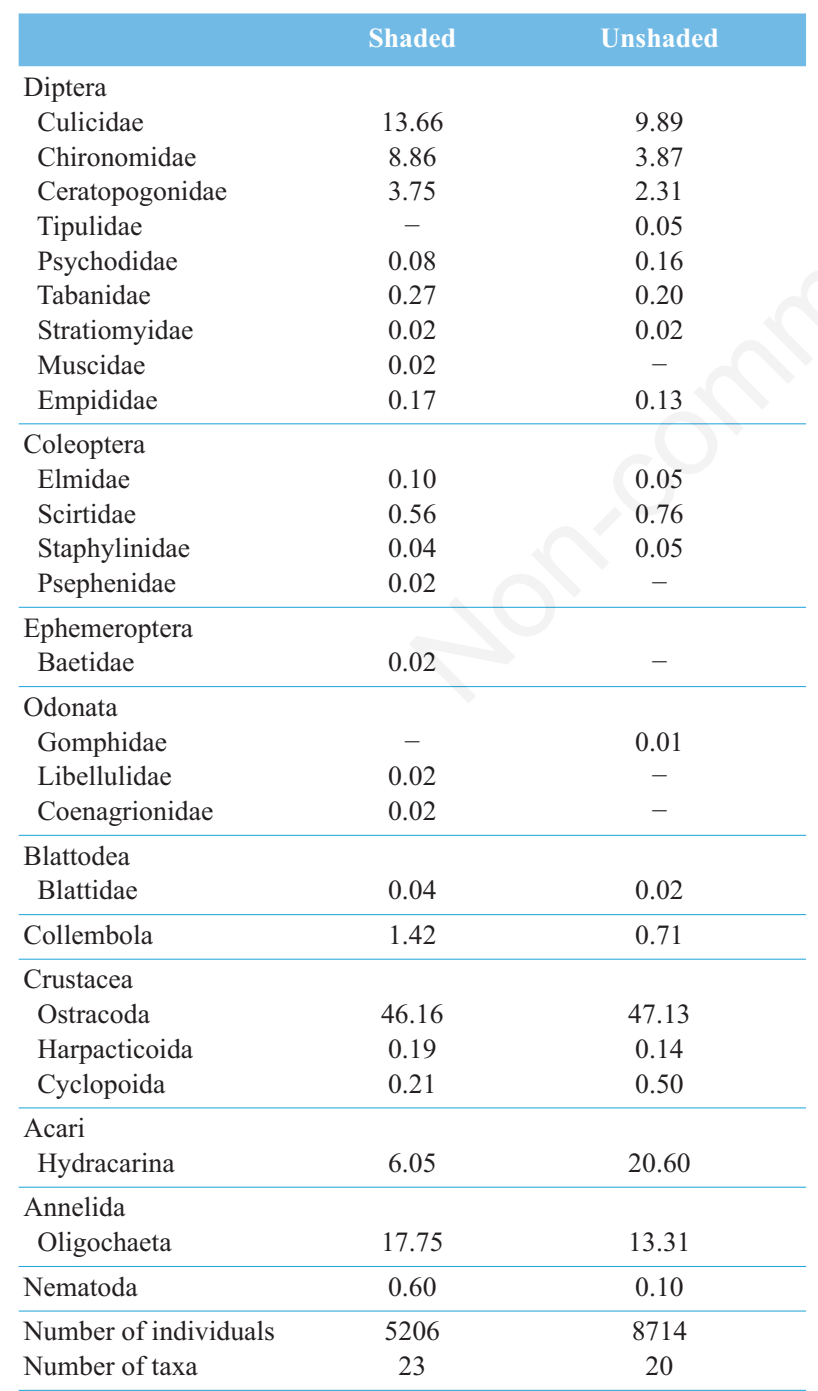

The structure of invertebrate communities varied more in shaded than unshaded bromeliads (Fig. 3). In both treatments, the communities observed in the experimental bromeliads were spatially distant from those observed in initial controls. However, invertebrate communities did not differ between treatments or colonization times (ANOSIM; treatment: $\mathrm{R}=0.020, \mathrm{P}=0.295$; time: $\mathrm{R}=0.018$, $\mathrm{P}=0.368$ ). Typical invertebrate shredders were absent in all samples from both treatments.

\section{DISCUSSION}

The colonization of tanks of $A$. lingulata by aquatic invertebrates was little influenced by the presence of
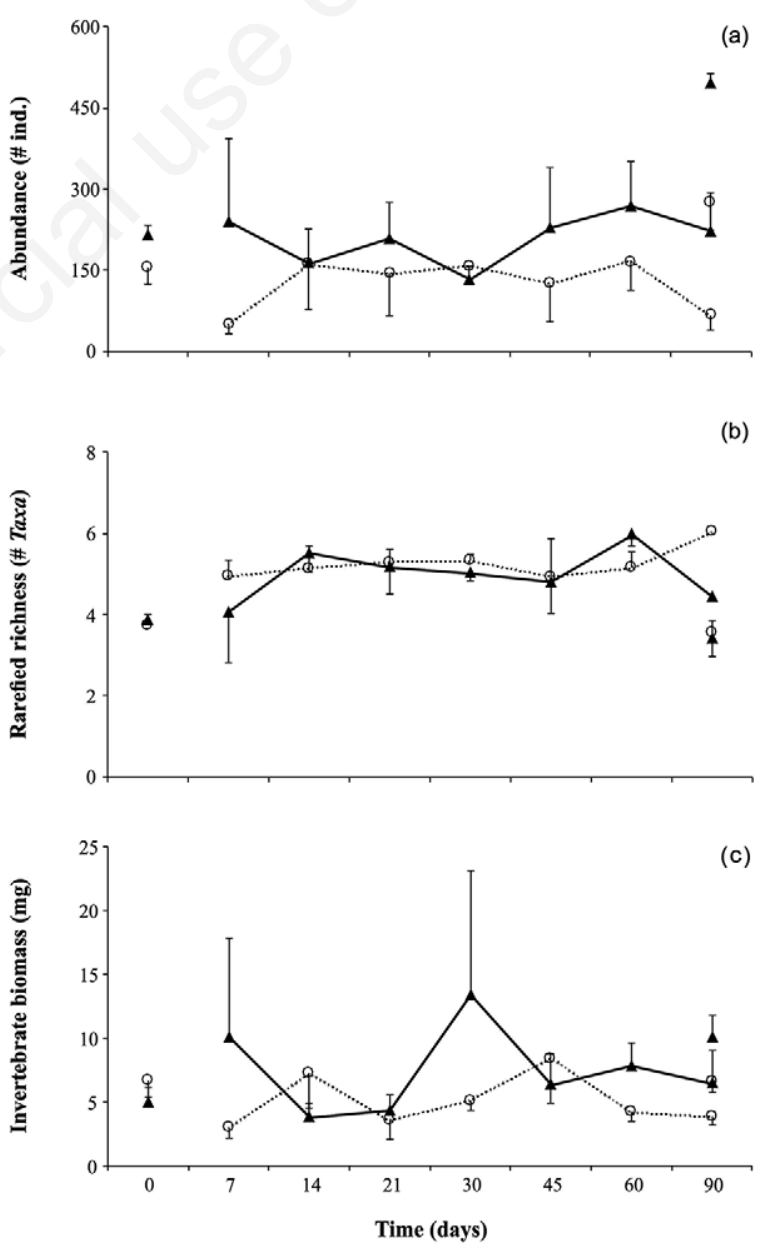

Fig. 2. Values of abundance (a), taxonomic richness (b) and biomass (c, mean $\pm \mathrm{EP})$ of invertebrate communities found in the phytotelmata of $A$. lingulata shaded (open circles, dotted line) and unshaded (solid triangles, solid line) by the canopy cover during the colonization experiment. Values not connected by lines represent the initial and final controls. 
canopy cover. Beyond values of light intensity and temperature of stored water, canopy cover influenced only the amount of CPOM in bromeliads. However, the volume of water and the amount of FPOM, which are important variables for the colonization process (Kitching, 2000; Armbruster et al., 2002; Dézerald et al., 2015b), did not differ between treatments and contributed to the high similarity of the communities sampled throughout the experiment. These results differ from those found in studies developed in tropical forest ecosystems (Montero et al., 2010; González et al., 2014) and are probably related to the characteristics of restinga (i.e., less dense vegetation composed of species adapted to low water availability and high temperatures and solar radiation) (Zaluar and Scarano, 2000; Scarano, 2002).

Some studies have suggested the volume of water is the main factor that influences the colonization of phytotelm ecosystems because it determines habitat size and susceptibility to colonization (Srivastava et al., 2008; Dézerald et al., 2014; Gossner et al., 2016). Although unshaded bromeliads have higher capacity of water collection (Dézerald et al., 2014), tanks held by these plants are also subject to higher evaporation rates as a result of direct exposure to solar radiation (Dézerald et al., 2015b; Buosi et al., 2015). In this study, the volumes of stored water differed only between colonization times and were related to rainfall values during the experiment. Because rosettes of $A$. lingulata had similar size and capacity of water storage, the absence of differences between treatments suggests that canopy cover provided by the restinga vegetation did not influence the rates of water collection and evaporation or the availability of habitat to aquatic invertebrates.

The accumulation of FPOM in bromeliad tanks oc- curred quickly and the amounts observed after one week were similar to those observed in initial and final control treatments (data not shown). According to Frank and Lounibos (2009), the amount of FPOM in phytotelmata may have different origins, including the excreta of animals and detritus produced by the decomposition of dead plants and animals. Moreover, these organic particles can be carried by the wind; therefore, FPOM input rates are not necessarily related to the presence of canopy cover (Ngai and Srivastava, 2006; Brouard et al., 2011). The amount of FPOM found in tanks of A. lingulata was independent of canopy cover and colonization times, as was observed by Dézerald et al. (2013) in tank-bromeliads sampled in different vegetation types.

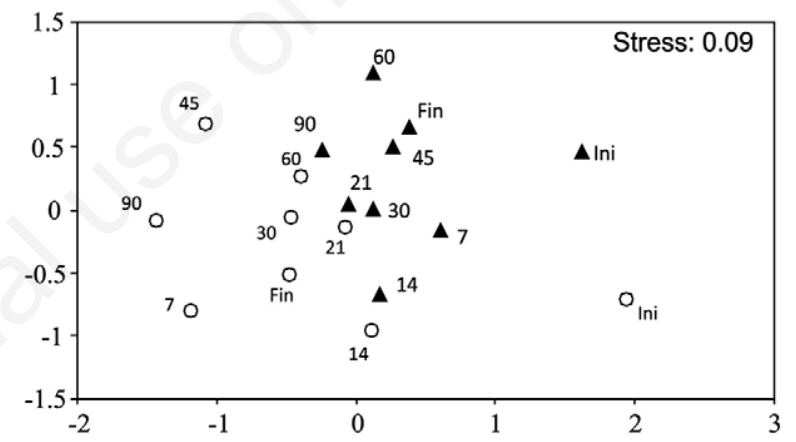

Fig. 3. Non-metric multidimensional scaling ordination of the invertebrate communities found in the phytotelmata of $A$. ling $u$ lata shaded (open circles) and unshaded (solid triangles) by the canopy cover. Labels indicate the colonization time (in days) and initial (Ini.) and final (Fin.) controls.

Tab. 3. Results of the Analyses of Variance (ANOVA) used to test for differences in the abundance, taxonomic richness and biomass $(\ln [\mathrm{x}+1]$ transformed data) of the invertebrate communities found in the phytotelmata of $A$. lingulata of different shade treatments and colonization times.

\begin{tabular}{|c|c|c|c|c|}
\hline & SS & df & F & $\mathbf{P}$ \\
\hline \multicolumn{5}{|l|}{ Abundance } \\
\hline Treatment & 7.656 & 1 & 6.171 & 0.017 \\
\hline Time & 5.463 & 6 & 0.734 & 0.625 \\
\hline Treatment $\times$ time & 6.287 & 6 & 0.845 & 0.543 \\
\hline Error & 52.102 & 42 & & \\
\hline \multicolumn{5}{|l|}{ Taxonomic richness } \\
\hline Treatment & 0.035 & 1 & 1.005 & 0.322 \\
\hline Time & 0.135 & 6 & 0.636 & 0.700 \\
\hline Treatment $\times$ time & 0.189 & 6 & 0.893 & 0.509 \\
\hline Error & 1.410 & 40 & & \\
\hline \multicolumn{5}{|l|}{ Biomass } \\
\hline Treatment & 0.379 & 1 & 0.746 & 0.393 \\
\hline Time & 1.462 & 6 & 0.481 & 0.819 \\
\hline Treatment $\times$ time & 1.164 & 6 & 0.383 & 0.886 \\
\hline Error & 20.290 & 40 & & \\
\hline
\end{tabular}

SS, sum of squares; $d f$, degrees of freedom. $R^{2}$ values=0.271 (abundance), 0.200 (taxonomic richness), 0.130 (biomass). 
As expected, larger amounts of CPOM were found in shaded bromeliads. However, high availability of plant detritus in this treatment did not result in significant differences in the taxonomic composition of invertebrate communities. Although CPOM represents an important energy source in many aquatic ecosystems (Vannote et al., 1980), typical invertebrate shredders were not found in the communities sampled. Organisms assigned to this functional feeding group have been observed in bromeliads of forest ecosystems (see Montero et al., 2010; Marino et al., 2012; González et al., 2014). Shredders are important to aquatic food webs because they provide food to other consumers (Graça, 2001). González et al. (2014) observed that the growth of the insect shredders Polypedilum sp. Kieffer, 1913 (Diptera, Chironomidae) and Phylloicus bromeliarum Müller, 1880 (Trichoptera, Calamoceratidae) was higher when exposed to leaf detritus enriched with nutrients ( $\mathrm{N}$ and $\mathrm{P}$ ) and suggested that leaf quality is also important to the development of shredders in bromeliad tanks. Possibly, the xeromorphic characteristics of leaf detritus produced in restinga, such as thick cuticles, wax deposition and high tannin content (Rôças et al., 1997; Boeger and Wisniewski, 2003; Mantuano et al., 2006), are related to the absence of typical shredders in the bromeliads studied. However, even with refractory characteristics, leaf detritus may contribute indirectly to maintenance of phytotelmata in the study area because they can provide nutrients to the host plants (Benzing and Renfrow, 1974; Inselsbacher et al., 2007).

Although phytotelmata constitute dynamic ecosystems subject to strong seasonal fluctuations (Cardoso et al., 2015; Amundrud and Srivastava, 2015; Ptatscheck and Traunspurger, 2015), values of abundance, taxonomic richness and biomass of the communities sampled in bromeliads did not differ among colonization times. Moreover, the experiment duration was long enough for all taxa present in controls to colonize tanks in both treatments. The absence of differences in most of the ecological parameters evaluated and the dominance of few taxa in shaded and unshaded bromeliads reflect the ecological filters provided by the studied ecosystems (Lopez and Rios, 2001; Lopez et al., 2009; Marino et al., 2012), which selected the colonizing organisms and resulted in communities with similar structure and taxonomic composition.

The abundances of Ostracoda and Hydracarina in the tanks of $A$. lingulata are likely related to the high resistance of these organisms to stressful environmental conditions, including desiccation (Smith et al., 2001; Di Sabatino et al., 2008; Rossi et al., 2011). The ability of some aquatic invertebrates to produce dormant eggs is an adaptation that favors success in bromeliad tanks (Williams, 1997, 2005). In addition, the passive dispersion presented by ostracods also contributes to the wide range of these organisms in phytotelm communities (Jocque et al., 2013). Alternatively, the low abundance of insects, compared to non-insect invertebrates, may be related to the high water temperatures in the bromeliads. Several authors have suggested that temperature is one of the factors that most affects the reproduction, growth and survival of insects, as well as predict their distribution and abundance on small temporal and spatial scales (Chesson and Huntly, 1997; Dixon et al., 2009; Dézerald et al., 2015a). In this context, the results obtained in this study corroborate the findings of Lopez and Rios (2001) in a restinga area of the State of Rio de Janeiro. The authors observed that Ostracoda was the most abundant taxon in bromeliad tanks, while insects, particularly the family Culicidae, were found in low abundance in unshaded bromeliads.

\section{CONCLUSIONS}

The obtained results showed that the canopy cover had a small influence on the colonization of tanks of A. lingulata by aquatic invertebrates. Consequently, the communities sampled in shaded and unshaded bromeliads were similar, not corroborating with the proposed hypothesis. These findings were likely a result of the lack of variation in environmental conditions that are relevant to the colonization process, such as the volume of water and the amount of FPOM. However, because the amount of CPOM was higher in shaded bromeliads, we believe that the taxonomic composition of sampled communities would differ if typical invertebrate shredders were present. The importance of organic detritus and primary production as energy sources to phytotelm ecosystems in the restinga should be better evaluated, given that the canopy cover does not seem to exert a significant influence on most environmental conditions and leaf litter has refractory characteristics that may affect the presence of certain functional groups.

\section{ACKNOWLEDGMENTS}

We thank Luiz Carlos de Araújo for assistance in the field and the Institute of Environment and Water Resources of the State of Espírito Santo (IEMA) for research permissions and logistical facilities. The Research Foundation of the State of Espírito Santo (FAPES; Proc. No. 61861480/2013) and the Brazilian National Research Council (CNPq; Proc. No. 449957/2014-4) for financial support in this study. FAPES provided Marcelo Moretti with a research fellowship (T.O. No. 0264/2016).

\section{REFERENCES}

Amundrud SL, Srivastava DS, 2015. Drought sensitivity predicts habitat size sensitivity in an aquatic ecosystem. Ecology 96:1957-1965. 
Armbruster P, Hutchinson R, Cotgreave P, 2002. Factors influencing community structure in a South American tank bromeliad fauna. Oikos 96:225-234.

Barberis IM, Torres PS, Batista WB, Magra G, Galetti L, Lewis JP, 2013. Two bromeliad species with contrasting functional traits partition the understory space in a South American xerophytic forest: correlative evidence of environmental control and limited dispersal. Plant Ecol. 215:143-153.

Benzing DH, Renfrow A, 1974. The mineral nutrition of Bromeliaceae. Bot. Gaz. 135:281-288.

Blaustein L, Schwartz SS, 2001. Why study ecology in temporary pools? Israel J. Zool. 47:303-12.

Boeger MRT, Wisniewski C, 2003. Comparação da morfologia foliar de espécies arbóreas de três estádios sucessionais distintos de floresta ombrófila densa (Floresta Atlântica) no Sul do Brasil. Rev. Bras. Bot. 26:61-72.

Brendonck L, Jocque M, Hulsmans A, Vanschoenwinkel B, 2010. Pools 'on the rocks': freshwater rock pools as model system in ecological and evolutionary research. Limnetica 29:25-40.

Brouard O, Céréghino R, Corbara B, Leroy C, Pelozuelo L, Dejean, A, Carrias, JF, 2012. Understorey environments influence functional diversity in tank-bromeliad ecosystems. Freshwater Biol. 57:815-823.

Brouard O, Le Jeune AH, Leroy C, Céréghino R, Roux O, Pelozuelo L, Dejean A, Corbara B, Carrias JF, 2011. Are algae relevant to the detritus-based food web in tankbromeliads? PloS one 6: e20129.

Buosi PRB, Cabral AF, Utz LRP, Vieira LCG, Velho LFM, 2015. Effects of seasonality and dispersal on the ciliate community inhabiting bromeliad phytotelmata in riparian vegetation of large tropical river. J. Eukaryot. Microbiol. 62:737-749.

Callisto M, Gonçalves JF, Graça MAS, 2007. Leaf litter as a possible food source for chironomids (Diptera) in Brazilian and Portuguese headwater streams. Rev. Bras. Zool. 24:442-448.

Cardoso CAA, Lourenço-De-Oliveira R, Codeço CT, Motta MA, 2015. Mosquitoes in bromeliads at ground level of the Brazilian Atlantic forest: the relationship between mosquito fauna, water volume, and plant type. Ann. Entomol. Soc. Am. 108:449-458.

Carrias JF, Céréghino R, Brouard O, Pélozuelo L, Dejean A, Couté A, Corbara B, Leroy C, 2014. Two coexisting tank bromeliads host distinct algal communities on a tropical inselberg. Plant Biol. 16:997-1004.

Chesson P, Huntly N, 1997. The roles of harsh and fluctuating conditions in the dynamics of ecological communities. Am. Nat. 150:519-53.

Clarke KR, Green RH, 1988. Statistical design and analysis for a 'biological effects' study. Mar. Ecol. Prog. Ser. 46:213-226.

Cogliatti-Carvalho L, Rocha-Pessôa TC, Nunes-Freitas AF, Rocha CFD, 2010. Volume de água armazenado no tanque de bromélias, em restingas da costa brasileira. Acta Bot. Bras. 24:84-95.

Costa C, Ide S, Simonka CE, 2006. Insetos Imaturos: Metamorfose e identificação. Holos, Ribeirão Preto: 233 pp.

Dézerald O, Leroy C, Corbara B, Carrias JF, Pélozuelo L, Dejean A, Céréghino R, 2013. Food-web structure in relation to environmental gradients and predator-prey ratios in tankbromeliad ecosystems. PloS one 8: e71735.

Dézerald O, Talaga S, Leroy C, Carrias JF, Corbara B, Dejean
A, Céréghino R, 2014. Environmental determinants of macroinvertebrate diversity in small water bodies: Insights from tank-bromeliads. Hydrobiologia 723:77-86.

Dézerald O, Céréghino R, Corbara B, Dejean A, Leroy C, 2015a. Temperature: diet interactions affect survival through foraging behavior in a bromeliad-dwelling predator. Biotropica 47:569-578.

Dézerald O, Céréghino R, Corbara B, Dejean A, Leroy C, 2015 b. Functional trait responses of aquatic macroinvertebrates to simulated drought in a Neotropical bromeliad ecosystem. Freshwater Biol. 60:1917-1929.

Di Sabatino A, Smit H, Gerecke R, Goldschmidt T, Matsumoto N, Cicolani B, 2008. Global diversity of water mites (Acari, Hydrachnidia; Arachnida) in freshwater. Hydrobiologia 595:303-315.

Dixon AFG, Honek A, Keil P, Kotela MAA, Sizling AL, Jarosík $\mathrm{V}, 2009$. Relationship between the minimum and maximum temperature thresholds for development in insects. Funct. Ecol. 23:257-264.

Domingos FMCB, Arantes IC, Cavalcanti DR, Jotta PACV, 2015. Shelter from the sand: microhabitat selection by the bromelicolous tree frog Scinax cuspidatus (Anura, Hylidae) in a Brazilian restinga. Northwest J. Zool. 11:27-33.

Dunthorn M, Stoeck T, Wolf K, Breiner HW, Foissner W, 2012. Diversity and endemism of ciliates inhabiting Neotropical phytotelmata. Syst. Biodivers. 10:195-205.

Frank JH, 1983. Bromeliad phytotelmata and their biota, especially mosquitoes, p. 101-128. In: J.H. Frank and L.P. Lounibos (eds.), Phytotelmata: terrestrial plants as hosts of aquatic insects communities, Plexus Publishing Inc.

Frank JH, Lounibos LP, 2009. Insects and allies associated with bromeliads: a review. Terr. Arthropod Rev. 1:125-153.

González AL, Romero GQ, Srivastava DS, 2014. Detrital nutrient content determines growth rate and elemental composition of bromeliad-dwelling insects. Freshwater Biol. 59:737-747.

Gossner MM, Lade P, Rohland A, Sichardt N, Kahl T, Bauhus J, Weisser WW, Petermann JS, 2016. Effects of management on aquatic tree-hole communities in temperate forests are mediated by detritus amount and water chemistry. J. Anim. Ecol. 85:213-226.

Gotelli NJ, Colwell RK, 2011. Estimating species richness, p. 39-54. In: A.E. Magurran and B.J. McGill (eds.), Biological diversity: frontiers in measurement and assessment. Oxford University Press.

Graça M, 2001. The role of invertebrates on leaf litter decomposition in streams - a review. Int. Rev. Hydrobiol. 86:383-393.

Graça MAS, Ferreira V, Canhoto C, Encalada AC, Guerrero-Bolaño F, Wantzen KM, Boyero L, 2015. A conceptual model of litter breakdown in low order streams. Int. Rev. Hydrobiol. 100:1-12.

Hammill E, Atwood TB, Corvalan P, Srivastava DS, 2015. Behavioural responses to predation may explain shifts in community structure. Freshwater Biol. 60:125-135.

IEMA [Instituto Estadual de Meio Ambiente e Recursos Hídricos]. [2015, September 8]. Available from: http:/www. meioambiente.es.gov.br

INMET [Instituto Nacional de Meteorologia]. [2013, October 9]. Available from: http://www.inmet.gov.br/portal

Inselsbacher E, Cambui CA, Richter A, Stange CF, Mercier H, 
Wanek W, 2007. Microbial activities and foliar uptake of nitrogen in the epiphytic bromeliad Vriesea gigantea. New Phytol. 175:311-320.

Jabiol J, Corbara B, Dejean A, Céréghino R, 2009. Structure of aquatic insect communities in tank-bromeliads in a EastAmazonian rainforest in French Guiana. Forest Ecol. Manag. 257:351-360.

Jocque M, Field R, 2014. Aquatic invertebrate communities in tank bromeliads: how well do classic ecological patterns apply? Hydrobiologia 730:153-166.

Jocque M, Frank F, Romero M, Martens K, 2013. Crustacea in phytotelmata: A global overview. J. Crustacean Biol. 33:451-460.

Kaufman MG, Wanja E, Maknojiia S, Bayoh MN, Vulule JM, Walker ED, 2006. Importance of algal biomass to growth and development of Anopheles gambiae larvae. J. Med. Entomol. 43:669-676.

Kitching RL, 2000. Food webs and container habitats: the natural history and ecology of phytotelmata. Cambridge University Press, Cambridge: 448 pp.

Kitching RL, 2001. Food webs in phytotelmata: "bottom-up" and "top-down" explanations for community structure. Annu. Rev. Entomol. 46:729-760.

Leroy C, Carrias JF, Corbara B, Pélozuelo L, Dézerald O, Brouard O, Dejain A, Céréghino R, 2013. Mutualistic ants contribute to tank-bromeliad nutrition. Ann. Bot. 112:919-926.

Liria J, 2007. Fauna fitotelmata en las bromelias Aechmea fendleri André y Hohenbergia stellata Schult del Parque Nacional San Esteban, Venezuela. Rev. Peru. Biol. 14:33-38.

Little TJ, Hebert PDN, 1996. Endemism and ecological islands: the ostracods from Jamaican bromeliads. Freshwater Biol. 36:327-338.

Lopez LCS, Rios RI, 2001. Phytotelmata faunal communities in sun-exposed versus shaded terrestrial bromeliads from Southeastern Brazil. Selbyana 22:219-224.

Lopez LCS, Alves RRN, Rios RI, 2009. Micro-environmental factors and endemism of bromeliad aquatic fauna. Hydrobiologia 625:151-156.

Magnago LFS, Pereira OJ, Matos FAR, Souza PF, 2007. Caracterização fitofisionômica da restinga na Morada do Sol, Vila Velha-ES. Rev. Bras. Biocien. 5:456-458.

Maguire B, 1971. Phytotelmata: Biota and community structure determination in plant- held waters. Annu. Rev. Ecol. Syst. 2:439-464.

Mantuano DG, Barros CF, Scarano FR, 2006. Leaf anatomy variation within and between three "restinga" populations of Erythroxylum ovalifolium Peyr. (Erythroxylaceae) in Southeast Brazil. Rev. Bras. Bot. 29:209-215.

Marino N, Srivastava D, Farjalla V, 2012. The phytotelmata and foliage macrofauna assemblages of a bromeliad species in different habitats and seasons. Insect Cons. Divers. 3:92-102.

McCune B, Grace JB, 2002. Nonmetric Multidimensional Scaling, p. 125-142. In: B. McCune, J.B. Grace, D.L. Urban (eds.), Analysis of Ecological Communities. MjM Software Design.

Merritt RW, Cummins KW, 1996. An introduction to the aquatic insects of North America. Kendall Hunt Publishing, Iowa: $862 \mathrm{pp}$.

Montero G, Feruglio C, Barberis IM, 2010. The phytotelmata and foliage macrofauna assemblages of a bromeliad species in different habitats and seasons. Insect Cons. Divers. 3:92-102.
Moore JC, Berlow EL, Coleman DC, Ruiter PC, Dong Q, Hastings A, Johnson NC, McCann KS, Melville K, Morin PJ, Nadelhoffer K, Rosemond AD, Post DM, Sabo JL, Scow KM, Vanni MJ, Wall DH, 2004. Detritus, trophic dynamics and biodiversity. Ecol. Lett. 7:584-600.

Mugnai R, Nessimian JL, Baptista DF, 2010. Manual de identificação de macroinvertebrados aquáticos do Estado do Rio de Janeiro. Technical Books, Rio de Janeiro: 174 pp.

Murrell EG, Ives AR, Juliano SA, 2014. Intrinsic and extrinsic drivers of succession: Effects of habitat age and season on an aquatic insect community. Ecol. Entomol. 39:316-324.

Naeem S, 1990a. Resource heterogeneity and community structure: A case study in Heliconia imbricata phytotelmata. Oecologia 84:29-38.

Naeem S, 1990b. Patterns of the distribution and abundance of competing species when resources are heterogeneous. Ecology 71:1422-1429.

Ngai JT, Srivastava DS, 2006. Predators accelerate nutrient cycling in a bromeliad ecosystem. Science 314:963-963.

Ospina-Bautista F, Varón JVE, Realpe E, Gast F, 2008. Diversidad de invertebrados acuáticos asociados a Bromeliaceae en un bosque de montaña. Rev. Col. Entomol. 34:224-229.

Petermann JS, Kratina P, Marino NAC, MacDonald AAM, Srivastava DS, 2015. Resources alter the structure and increase stochasticity in bromeliad microfauna communities. PloS one $10, \mathrm{e} 0118952$.

Ptatscheck C, Traunspurger W, 2015. Meio and macrofaunal communities in artificial water-filled tree holes: Effects of seasonality, physical and chemical parameters and availability of food resources. PloS one 10, e 0133447.

Richardson BA, 1999. The bromeliad microcosm and the assessment of faunal diversity in a Neotropical forest. Biotropica 31:321-336

Richardson BA, Hull GA, 2000. Insect colonization sequences in bracts of Heliconia caribaea in Puerto Rico. Ecol. Entomol. 25:460-466.

Rôças G, Barros CF, Scarano FR, 1997. Leaf anatomy plasticity of Alchornea triplinervia (Euphorbiaceae) under distinct light regimes in a Brazilian montane Atlantic rain forest. Trees 11:469-473.

Rossi V, Benassi G, Belletti F, Menozzi P, 2011. Colonization, population dynamics, predatory behaviour and cannibalism in Heterocypris incongruens (Crustacea: Ostracoda). J. Limnol. 70:102-108.

Scarano FR, 2002. Structure, function and floristic relationships of plant communities in stressful habitats marginal to the Brazilian Atlantic rain in forest. Ann. Bot. 90:517-524.

Scarano FR, Duarte HM, Rôças G, Barreto SMB, Amado EF, Reinert F, Wendt T, Mantovani A, Lima HRP, Barros CF, 2002. Acclimation or stress symptom? An integrated study of intraspecific variation in the clonal plant Aechmea bromeliifolia, a widespread CAM tank-bromeliad. Bot. J. Linn. Soc. 140:391-401.

Smith IM, Cook DR, Smith BP, 2001. Water mites (Hydrachnida) and other arachnids, p. 551-659. In: J.H. Thorp and AP Covich (eds.), Ecology and classification of North American freshwater invertebrates. Academic Press.

Srivastava DS, 2006. Habitat structure, trophic structure and ecosystem function: interactive effects in a bromeliad-insect community. Oecologia 149:493-504. 
Srivastava DS, Kolasa J, Bengtsson J, González A, Lawler S, Miller TE, Munguia P, Romanuk T, Schneider DC, Trzcinski MK, 2004. Are natural microcosms useful model systems for ecology? Trends Ecol. Evol. 19:379-384.

Srivastava DS, Trzcinski MK, Richardson BA, Gilbert B, 2008. Why are predators more sensitive to habitat size than their prey? Insights from bromeliad insect food webs. Am. Nat. 172:761-771.

Triplehorn CA, Johnson NF, 2011. Estudo dos insetos. Cengage Learning, São Paulo: 810 pp.

Vannote RL, Minshall GW, Cummins KW, Sedell JR, Cushing CE, 1980. The river continuum concept. Canadian J. Fish. Aquat. Sci. 37:130-137.

Vieira L, Louzada JNC, Spector S, 2008. Effects of degradation and replacement of Southern Brazilian coastal sandy vegetation on the dung beetles (Coleoptera: Scarabaeidae). Biotropica 40:719-727.

Walker ED, Merritt RW, Kaufman MG, Ayres MP, Riedel MH, 1997. Effects of variation in quality of leaf detritus on growth of the eastern tree-hole mosquito, Aedes triseriatus (Diptera: Culicidae). Can. J. Zool. 75:706-718.

Williams DD, 1997. Temporary ponds and their invertebrate communities. Aquat. Conserv. 7:105-117.

Williams DD, 2005. Temporary forest pools: can we see the water for the trees? Wetl. Ecol. Manag. 13:213-233.

Yee DA, Willig MR, 2007. Colonisation of Heliconia caribaea by aquatic invertebrates: resource and microsite characteristics. Ecol. Entomol. 32:603-612.

Zaluar HLT, Scarano FR, 2000. Facilitação em restingas de moitas: um século de buscas por espécies focais, p. 3-23. In: F.A. Esteves and L.D. Lacerda (eds.), Ecologia de restingas e lagoas costeiras. Universidade Federal do Rio de Janeiro.

Zar JH, 2010. Biostatistical Analysis. 5. Pearson/Prentice-Hall, New Jersey: 944 pp.

Zytynska SE, Khudr MS, Harris E, Preziosi RF, 2012. Genetic effects of tank-forming bromeliads on the associated invertebrate community in a tropical forest ecosystem. Oecologia 170:467-475. 